\title{
Effect of Age, Education, Income Gross, and Moral of Compliance Tax Payments \\ (Case Study on Personal Taxpayers at KPP Pratama Jakarta Kramatjati)
}

\author{
Hasian Purba \\ Accounting Study Program, Faculty of Economics and Business, Universitas Mercu Buana
}

\begin{abstract}
The purpose of this study is as follows: 1) Finding empirical evidence about the effect of the age of taxpayers on tax payment compliance; 2) Finding empirical evidence regarding the influence of taxpayer education on compliance with tax payments; 3) Finding empirical evidence regarding the effect of the taxpayer's gross income on tax payment compliance; 4) Finding empirical evidence about the moral influence of taxpayers on tax compliance. This type of research used in this study is causal. The population in this study are all individual taxpayers who are registered in KPP Pratama Jakarta Kramatjati. Sample selection with purposive sampling method. The analytical method used to test hypotheses is the multiple regression test. The results showed, 1) Age Taxpayers have a positive effect on tax compliance; 2) Taxpayer Education has a positive effect on compliance with paying taxes; 3) Gross income of the taxpayer has no effect on compliance with paying taxes; 4) Moral Taxpayers have a positive effect on compliance with paying taxes.
\end{abstract}

Keywords: Age, Education, Gross Income, Moral, Compliance Tax Payments

DOI: $10.7176 / \mathrm{EJBM} / 11-27-12$

Publication date:September $30^{\text {th }} 2019$

\section{INTRODUCTION}

The Directorate General of Taxes is an institution under the Ministry of Finance of the Republic of Indonesia whose job is to secure state revenue from the taxation sector. Every year, the target of state revenue from the taxation sector is always increasing. This is in line with the government's expectation that in the future the taxation sector can finance all development financing.

Based on the Law of the Republic of Indonesia Number 28 of 2007 concerning the third amendment to Law Number 6 of 1983 concerning general provisions and procedures for taxation article 1 paragraph 1 states that tax is a compulsory contribution to a compulsive state based on the Act, with no get compensation directly and be used for the needs of the country for the maximum prosperity of the people.

\section{Table 1.1}

Proportion of Tax Revenue to State Revenue 2012-2016

\begin{tabular}{|c|r|r|c|}
\hline $\begin{array}{c}\text { Year } \\
\text { The budget }\end{array}$ & $\begin{array}{c}\text { State Revenue } \\
\text { (in Trillions) }\end{array}$ & $\begin{array}{c}\text { Tax revenue } \\
\text { (in Trillions) }\end{array}$ & $\begin{array}{c}\text { Percentage } \\
\text { \% }\end{array}$ \\
\hline 2012 & $1.338,10$ & 980,50 & 73,28 \\
\hline 2013 & $1.438,90$ & $1.077,30$ & 74,87 \\
\hline 2014 & $1.550,50$ & $1.146,90$ & 73,97 \\
\hline 2015 & $1.761,60$ & $1.489,20$ & 84,54 \\
\hline 2016 & $1.822,50$ & $1.546,70$ & 84,87 \\
\hline
\end{tabular}

Source: Ministry of Finance Official Website (2018)

Based on Table 1.1, tax revenue from year to year always increases. Taxes contributed quite high in state revenue for five years from 2012-2016, with a percentage above 70\%, even reaching 84.5\% in 2015 and 2016. This reflects that tax plays an important role in the APBN.

The high tax revenue in a country should be balanced with a high tax ratio. Tax ratio is the ratio between the amount of tax revenue and the gross domestic product (GDP) of a country. According to Simanjuntak and Mukhlis, 2012, "Tax ratio is one indicator used by the government to measure success in state revenue from taxes". In fact, despite increased tax revenue, Indonesia has a relatively low tax ratio, this shows that the government has not been successful in optimizing tax revenue.

Various businesses that have been carried out by the Directorate General of Taxes to continuously increase the amount of tax revenue include the effort of tax intensification and intensification which is an action that has been declared by the Directorate General of Taxes in order to increase tax revenue, namely by expanding tax subjects and objects or by capturing taxpayers new. On the other hand, the dynamic development of small and medium-sized businesses may well be far from tax coverage. Even though the safety net for Taxpayers in the form of NPWP (Taxpayer Identification Number) in order to be able to carry out their tax obligations has been 
installed, especially for the small and medium businesses, but still found small and medium businesses that are free from tax havens. Actually there are still many potential taxpayers who have not been registered as actual taxpayers. Disobedience in paying taxes does not only occur in the employer layer but it is common knowledge that other professional workers are also disobedient to pay taxes.

Tax collection is indeed not an easy job, in addition to the active participation of tax officials, it is also required to obey the taxpayers themselves in paying taxes. Where according to taxation laws, Indonesia adopts a self-assessment system that gives taxpayers confidence in calculating, depositing and self-reported tax payable, causing the correctness of tax payments depending on the honesty of taxpayers themselves in reporting tax obligations.

The most important thing in tax collection is that there must be Taxpayer Compliance in paying tax obligations. Compliance with paying tax (tax compliance) is that taxpayers have a willingness to meet their tax obligations in accordance with applicable regulations without the need for inspection, careful investigation, warning, or threat and the application of sanctions both legal and administrative (Simon James et al in Elin and Susi , 2019). Considering that taxpayer compliance is an important and main factor for increasing tax revenue, it is necessary to continuously examine what factors influence tax compliance, especially individual taxpayers.

Research on tax compliance is often done. Some studies use the Theory of Planned Behavior (TPB) model framework to explain tax compliance behavior by individual taxpayers (Aryati 2012, Isthi 2013; Wening and Indra 2014). According to Ajzen (1988 in Isthi 2013) who proposed "Theory of Planned Behavior", a person's behavior depends on behavioral intention.

Theory of Planned Behavior is a tool that can be used to predict individual behavior when the individual does not have complete control of their own will. The TPB model used in the study will provide a significant explanation, that the non-compliance behavior of the Taxpayer is strongly influenced by variables of age, education, income, and moral obligations.

The age of the taxpayer is one of the most important factors that determine tax compliance. Tittle (1980 in Isthi 2013) explains the relationship between age and tax non-compliance caused by experience and generational differences. Younger taxpayers, who are more willing to take risks, are less sensitive to punishment, and social reflexes and psychological differences relate to periods where they are ranked highest (generational differences). Isthi's research (2013) found that older taxpayers are usually more obedient than younger taxpayers. These studies are in line with Kurniati's (2011) research on the Analysis of the Effects of Socialization, Sanctions and Demographic Factors on the Compliance of UN Taxpayers in Surakarta, the results of which can be concluded that age has a positive effect on the opportunities of taxpayers to comply with UN

The level of public education in general can affect the compliance of taxpayers in fulfilling their tax obligations. The higher level of public education will make it easier for the public to understand the provisions and regulations in the field of taxation in force. The low level of education will also be reflected in the large number of taxpayers, especially individuals who have free work who do not keep books or who do double bookkeeping for tax purposes. A low level of education will also have the opportunity for taxpayers to be reluctant to carry out their tax obligations due to their lack of understanding of the taxation system applied. Research by Isthi (2013) and Dewi, et al (2014) concluded that the level of taxpayer education has a statistically significant effect on taxpayer compliance.

Someone who has a high income level tends to report his taxes more honestly than those who have low income. Ishti (2013) in his research which concluded that taxpayer's income had a positive effect on taxpayer compliance in meeting tax obligations.

Moral obligation is another attempt to maximize taxpayer compliance. According to Ajzen (2002), ethics, principles of life, feelings of guilt are moral obligations that each person has in carrying out something. Where this can be associated with compliance with taxpayers in paying taxes. This is in line with research conducted by Aryati (2012) and Ishti (2013) where the level of tax compliance will be higher when taxpayers have stronger moral obligations.

For reasons like the above, this study intends to examine the age of taxpayers, education taxpayers, gross income of taxpayers, moral taxpayers, and taxpayer compliance on personal taxpayers at the Jakarta Kramatjati Tax Office with the title: Effect Age, Education, Gross Income, and Morals towards Tax Payment Compliance (Case Study on Personal Taxpayers at KPP Pratama Jakarta Kramatjati)

\section{LITERATURE REVIEW}

\section{Attribution Theory}

Relationship theory has been proposed to develop an explanation of the ways we value individuals differently, depending on the meaning we associate with certain behaviors. Basically, this theory suggests that when observing an individual's behavior, we try to determine whether the behavior is caused internally or externally. (Robbins, 2008 in Sri, 2018)

Behavior that is caused internally is behavior that is believed to be under the personal control of that 
individual. Behavior that is caused externally is seen as a result of external causes, that is, the person is seen as forced to behave thus by the situation. (Robbins, 2008 in Sri, 2018).

The reason for choosing this theory is the willingness of taxpayers to pay taxes related to taxpayers in making an assessment of the tax itself. Aiming to make an assessment of someone's perception of something is strongly influenced by internal and external conditions of the person. So the theory of attribution is very relevant to explain this intention.

\section{Social Learning Theory}

Social learning theory states that a person can learn through direct observation and experience (Bandura, 1977 in Ishti, 2013). According to Bandura (1977) in Ishti (2013), the process in social learning includes: 1). Attentional process; 2). Retention process; 3). Motor reproduction process; and 4). Strengthening process

This social learning theory is relevant to explain the behavior of taxpayers in fulfilling their tax obligations. Someone will be obedient to pay taxes on time if through observation and direct experience, the tax money they pay has made a real contribution to the development in their area.

\section{Theory of Reasoned Action}

Theory Reasoned Action was first coined by Ajzen in 1980. This theory was prepared using the basic assumption that humans behave in a conscious manner and consider all available information. According to Fishbein and Ajzen (1975) in Jogiyanto (2015), attitude is the amount of affection (feeling) a person feels to accept or reject an object or behavior and is measured by a procedure that places individuals on a two-pole evaluative scale, for example good or bad, agree or reject and so on. Furthermore, subjective norms are defined as one's perceptions or views of other people's beliefs that will influence the intention to do or not perform the behavior under consideration (Jogiyanto, 2015).

According to Gibbon et al (1998), rational thinking processes mean that in every voluntary behavior there will be a decision making process that is concretely manifested in the intention to carry out a behavior. Further explained by Eagley and Chaiken (1993) that in the framework of a theory of reasoned action, attitudes are transformed indirectly in the form of open behavior through the mediation of psychological processes called intentions. Therefore it can be concluded that intention is a psychological process whose existence lies between attitude and behavior.

Many studies in the social field have proven that Theory of Reason Action (TRA) is a sufficient theory in predicting behavior. However, after a few years, Ajzen conducted a meta-analysis, it was found that a conclusion that Theory Reason Action (TRA) only applies to behavior that is under the complete control of the individual because there are factors that can hinder or phallize the relation of intention into behavior. Based on this analysis, Ajzen then added a factor related to individual control, namely perceived behavior control (PBC). Adding one factor then changes the Theory of Reason Action (TRA) to Theory of Planned Behavior (TPB).

\section{Theory of Planned Behavior}

According to Ajzen (2002) "Theory of Planned Behavior (TPB) explains that behavior determined by individuals arises because there is an interest in behavior. There are three behavioral factors that influence the intention to behave. That is : 1) Behavioral beliefs are individual beliefs about the results of a behavior and evaluation of these resultan; 2) Normative beliefs are beliefs about the normative expectations of others and motivation to meet these expectations; and 3) Control beliefs are beliefs about the existence of things that support or hinder the behavior that will be displayed and their perception of how strong the things that support and hinder their behavior (perceived power)".

Bobek \& Hatfield (2003) and Hanno \& Violette (1996), used Theory of Planned Behavior (TPB) to explain tax compliance for individual taxpayers with the finding that attitudes toward tax non-compliance significantly influence the intention of tax non-compliance. So in this study, Theory of Planned of Behavior is relevant to explain the behavior of taxpayers in fulfilling their tax obligations.

\section{Taxpayer Compliance}

Based on the self assessment system adopted in Indonesia, the Personal Tax Income Taxpayer is given the freedom to calculate and calculate their own tax payable, by taking, filling, submitting the Annual Personal Tax Return, and depositing the tax owed. Based on this self-assessment system, according to Budiatmanto (1999 in Aryati, 2012), taxpayer compliance is indicated by the intensity of taxpayers to submit tax returns regularly. Therefore SPT is a very important factor and is related to Taxpayer Compliance.

According to Zain (2003 in Aryati 2012) the understanding of taxpayer compliance is a climate of compliance and awareness of fulfillment of tax obligations, which is reflected in situations where taxpayers understand and try to understand all the provisions of tax legislation, complete tax forms completely and clearly, calculate the amount of tax owed correctly and pay tax owed on time. 
Based on the explanation of the compliance of the Personal Taxpayer that was found, and from the understanding of compliance that had also been found before, it became clear that the compliance of the Personal Taxpayer contained two main points. First, the willingness of an Individual Taxpayer to report income properly in the Annual Tax Return and deposit and report the Tax Return in due time in accordance with applicable laws, rules and court decisions. Second, the request to fill out and report the Annual Personal Tax Return according to the applicable laws and regulations, is a direct request from the tax authority (tax authorities), so that the Taxpayer in general and the Individual Obligatory Tax Obligation in particular behave in compliance first to get a reaction which is pleasing or even avoids the punishment of those who have authority, as a consequence of the behavior carried out.

\section{Criteria for Compliant Taxpayers}

Compliant taxpayers are taxpayers determined by the Directorate General of Taxes as taxpayers who meet certain criteria referred to in the decision of the Minister of Finance number 544 / KMK.04 / 2000 concerning the criteria of compliant taxpayers who can be given preliminary excess tax enrichment as amended by the decision of the Minister of Finance number 235 / KMK.3 / 2003, that the criteria for taxpayers are as follows: 1) Timely in submitting the Annual Tax Return in the last 2 (two) tax periode; 2) Do not have tax arrears for all types of taxes; 3) Has never been sentenced for committing a criminal act in the field of taxation within 10 (ten) years; 4) In the case of financial statements, audited by a public accountant, and must be with the opinion of:; and 5) In the case of a financial report that is not audited by a public accountant, the Taxpayer may submit an application to be determined as a compliant Taxpayer as long as:

So compliant taxpayers are taxpayers who obey and fulfill and carry out tax obligations in accordance with the provisions of tax legislation and applicable implementing regulations.

\section{Factors that can affect compliance in paying taxes}

Jackson and Milliron (in Ishti, 2013) identified 14 factors that can affect compliance in paying taxes, namely age, sex, education, income level, source of income, employment, relationship influence, ethics or morals, perceptions of the fairness of the tax system, complexity (tax system), relationships with the authorities who receive tax, detection opportunities (possibly audited), legal sanctions and tax rates. Several factors mentioned by Jackson and Milliron are demographic factors, namely factors related to population structure and factors that can cause changes in population structure. In this study, demographic factors investigated included age, education, income, and morality of taxpayers.

\section{a. Age}

The age of the taxpayer is one of the most important factors that determine tax compliance. Previous studies have found that older taxpayers are usually more obedient than younger taxpayers (Ishti, 2013). Tittle (1980 in Ishti, 2013) explains the relationship between age and tax non-compliance caused by experience and generational differences. Younger taxpayers, who are more willing to take risks, are less sensitive to punishment, and social reflexes and psychological differences relate to periods where they are ranked highest (generational differences).

\section{b. Education}

In this study, the age of respondents was grouped into 2 groups: (1) 17-39 years, (2) 40 years and over.

According to Bida (2001 in Aryati, 2012), taxpayer education is an effort made by taxpayers in building attitudes and behavior, knowledge and skills through teaching and training that are useful for its development in society and the state. The higher level of public education will make it easier for the public to understand the provisions and regulations in the field of taxation in force. The level of education that is still low will also be reflected in the large number of taxpayers, especially individuals who do not keep books or who do double bookkeeping for tax purposes. Education is not just a school but the formation of the concept of behavior and patterns of community life. Because people in their relationships are always trying to adjust to their environment, so the educational process and its influence is very important for one's development.

Ikhsan (2007 in Ishti, 2013) states that in general the higher the level of education of taxpayers, the easier it is for them to understand tax regulations. Taxpayers who already understand taxation regulations, including understanding administrative sanctions and fiscal penalties, are expected to meet their tax obligations. If taxpayers are able to understand tax regulations well, then they will fulfill their obligations in paying taxes regularly.

In this study, the latest education level of taxpayers is divided into 2 levels, namely: (1) the category of low education (elementary / junior high / high school) and (2) the category of higher education (Diploma / Bachelor).

\section{c. Gross Income}

Income according to Mardiasmo (2016) is any additional economic capability received or obtained by taxpayers, both from Indonesia and from outside Indonesia, which can be used for consumption or to add to 
the wealth of the taxpayers concerned, with any name and form. The definition or definition of gross income according to tax provisions is the sum of all gross income received or obtained by taxpayers in connection with work during the tax year concerned from each employer. Income can be in the form of salaries / pension / old age benefits (THT), income tax benefits, other benefits, compensation, overtime pay, etc., honorariums, other benefits of the same type, insurance premiums paid by employers, receipts in kind and other enjoyments that are subject to withholding Article 21 Income Tax, and bonuses, bonuses, gratuities, production services, THR.

Since this research was prepared in 2019, in this study the amount of income is grouped by considering the Regional Minimum Wage (UMR) level in Jakarta in 2019, namely: (1) Gross Income Category ranges from $\mathrm{Rp} 2.7$ to 5.4 million and (2) Gross income category above 5.5 million.

\section{d. Moral}

Theory of moral reasoning can be used to explain the influence of taxpayer morals on taxpayer compliance. This theory states that moral decisions can be influenced by tax sanctions at low levels of moral reasoning, peer expectation (expectations of justice) at moderate levels, and issues of fairness (fairness) at the highest levels. Taxpayers who use more moral principles in making tax payment decisions will be more obedient than other taxpayers.

Moral aspects in the field of taxation involve two things, namely (1) taxation obligations are moral obligations that must be fulfilled by each taxpayer, and (2) concerns moral awareness related to the allocation or distribution of tax revenue. Taxpayers who have good moral awareness as citizens in carrying out their tax obligations are different from citizens who do not have moral awareness. Thus it is expected that the morality aspect of taxpayers will increase the tendency of taxpayers to meet their tax obligations.

\section{Prior Research}

Previous studies that can support this research are as follows: Cahyonowati (2011) conducted research on the model and compliance of taxation of individual taxpayers. This study aims to examine the level of tax compliance of individual taxpayers and the factors that influence it. The moral level of taxation is predicted to affect the level of tax compliance. This study found that the moral level of taxpayers in Indonesia has not grown from individual intrinsic motivation but rather the implementation of external factors, namely the amount of tax penalties.

Kurniati \& Fevriera (2011) in her study entitled "Analysis of the Effects of Socialization, Sanctions and Demographic Factors on Compliance with UN Taxpayers in Surakarta. The results showed that age and education level of taxpayers had a positive effect on taxpayer compliance while taxpayers' income had a negative effect on taxpayer compliance.

Aryanti (2012) in her research entitled "Analysis of Factors Affecting the Compliance Level of Corporate Taxpayers". This study found that attitudes, gender, and morals significantly influence the level of compliance of corporate taxpayers. While age, education, income level, and environment have no effect and are not significant to the level of compliance of corporate taxpayers.

Isthi (2013) in his research entitled "The Effect of Age, Education, Gross Income, and Moral Against Tax Payment Compliance (Empirical Study of Entrepreneurship WPOP on Mall Ciputra)". The results showed that 1) the age of taxpayers had a positive and significant effect on tax compliance; 2) Taxpayer Education has a positive and significant effect on compliance with paying taxes; 3) Gross Income Tax Income has a positive and significant effect on tax compliance; 4) Moral Taxpayers have a positive and significant effect on compliance with paying taxes.

Dewi, et al (2014) in their study entitled "The Effect of Gender, Occupational Background, and Education Level on Taxpayer Compliance. Based on ANOVA results, gender does not have an effect on taxpayer compliance, while occupational background and level of education have an influence on taxpayer compliance in meeting tax obligations. In addition, there is also a joint effect of gender, occupational background and level of education on taxpayer compliance.

\section{Research Framework}

Based on the research problem supported by the theoretical foundation and previous research, the research model can be described as follows: 


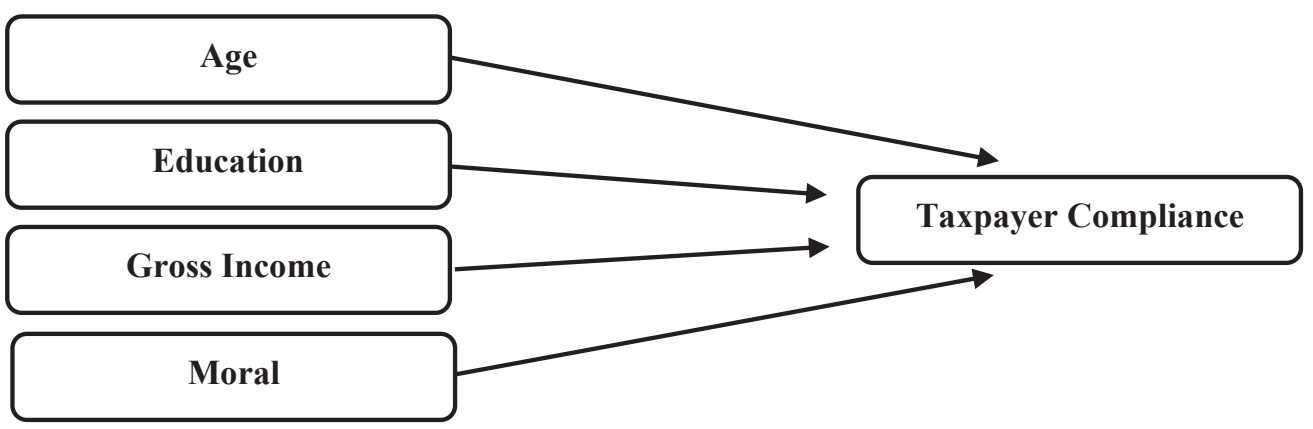

Gambar 1.1 Model Penelitian

\section{Hypothesis}

The research hypotheses proposed are as follows:

Ha1: The taxpayer's age affects the compliance of tax payments.

Ha2: Education influences taxpayers' compliance with tax payments.

Ha3: Gross income of the taxpayer affects the compliance of tax payments.

Ha4: Moral taxpayers affect tax compliance.

\section{RESEARCH METHODS}

\section{Types of research}

This research is causal which will test the hypothesis about the effect of one or several independent variables on the dependent variable. According to Sarwono and Suhayati (2010) causal research is research conducted to identify causal relationships between variables. Causal research is aimed at finding out which variables function as causes (independent variables) and which variables function as results (dependent variables).

\section{Definition of Variable Operations}

The variables used in this study consisted of one dependent variable, four independent variables. Operational research variables can be summarized in the following table:

Table 1.2 Operationalization of Variables

\begin{tabular}{|c|c|c|c|}
\hline Variables & Concept Variables & Indicator & Scale \\
\hline \multicolumn{4}{|l|}{ Dependent } \\
\hline $\begin{array}{l}\text { Tax Payment } \\
\text { Compliance }(Y)\end{array}$ & $\begin{array}{l}\text { Willingness to report and pay } \\
\text { taxes in accordance with } \\
\text { applicable laws }\end{array}$ & $\begin{array}{l}\text { - Compliance with SPT Submission } \\
\text { - Compliance Payment } \\
\text { - Comply with reporting }\end{array}$ & Likert \\
\hline \multicolumn{4}{|l|}{ Independent } \\
\hline Age $\left(X_{1}\right)$ & Age of Respondents & $\begin{array}{l}\text { - The young category for ages } 17-39 \text { years } \\
\text { - Old age categories above } 40 \text { years old }\end{array}$ & dummy \\
\hline Education $\left(\mathrm{X}_{2}\right)$ & $\begin{array}{ll}\text { Latest education } & \text { level } \\
\text { Respondents } & \end{array}$ & $\begin{array}{l}\text { - Low education category (elementary / } \\
\text { junior high / high school) } \\
\text { - Higher education categories (Diploma / } \\
\text { Bachelor degree) }\end{array}$ & dummy \\
\hline $\begin{array}{l}\text { Gross Income } \\
\left(\mathrm{X}_{3}\right)\end{array}$ & Total taxpayer income in monthly & $\begin{array}{l}\text { - The Gross Income category ranges from } \\
\text { Rp } 2.7 \text { to } 5.4 \text { million and } \\
\text { - Gross income category above } 5.5 \\
\text { million }\end{array}$ & dummy \\
\hline Moral $\left(\mathrm{X}_{4}\right)$ & $\begin{array}{l}\text { Moral principles or individual } \\
\text { values related to the willingness to } \\
\text { pay taxes. }\end{array}$ & $\begin{array}{l}\text { - measuring someone's attitude if not } \\
\text { reporting obligations } \\
\text { - have a willingness to pay taxes }\end{array}$ & Likert \\
\hline
\end{tabular}

\section{Variable Measurement}

To measure the variables to be studied, the research instrument was used. The measurement of variables is as follows:

\section{Tax Payment Compliance (Y)}

Tax Payment Compliance is measured by 5 Likert scales, namely: value $1=$ Strongly Disagree, $2=$ Disagree, $3=$ Doubtful, $4=$ Agree, $5=$ Strongly Agree.

2. Age (X1)

Age is measured by dividing it into 2 categories. The young category for ages 17-39 years and the old 
category for ages over 40 years. With age divided into 2 categories, then given a score or called a dummy variable where 0 for the young category and 1 for the old category.

3. Education (X2)

Education is measured by dividing it into 2 categories. The category of lower education (SD/SMP/SMA) and the category of higher education (Diploma/Bachelor). With the division of Education into 2 categories, it is given a score or called a dummy variable where 0 is for the lower education category and 1 is for the higher education category.

4. Gross Income (X3)

Gross income is measured by dividing it into 2 categories. The Gross Income category ranges from Rp 2.7 to 5.4 million and the Gross Income category above 5.5 million. With the division of Gross Income into 2 categories, it is given a score or called a dummy variable where 0 for Gross Income ranges from $\mathrm{Rp} 2.7$ to 5.4 million and 1 for the Gross Income category above 5.5 million.

5. Moral (X4)

Moral is measured on a 5 Likert scale: $1=$ Strongly Disagree, $2=$ Disagree, $3=$ Doubtful, $4=$ Agree, $5=$ Strongly Agree.

\section{Population and Research Samples}

The population of this research is all individual taxpayers who are registered in Jakarta Kramatjati Tax Office.

Sampling in this study was conducted using a purposive sampling method. The data obtained by researchers from the Jakarta KPP Pratama Kramatjati, researchers obtained the number of individual taxpayers who do business as much as 7,591 taxpayers. From a population that is clearly known, the calculation of sampling using the Slovin formula is as follows:

$$
\begin{aligned}
& n=\frac{N}{1+N e^{2}} \\
& n=\frac{7591}{1+7591(10 \%)^{2}} \\
& n=\frac{7591}{76,91} \\
& n=98,6998, \text { rounded to } 99
\end{aligned}
$$

Based on these calculations the number of samples in this study were 99 Individual Taxpayers who were registered at the KPP Pratama Jakarta Kramatjati.

\section{Data collection technique}

The method of data collection in this study was carried out by the sampling method, which is a method of investigation conducted to obtain facts or symptoms that exist and look for facts factually. Data collection is done through a questionnaire given to individual taxpayers who are registered at KPP Pratama Jakarta Kramatjati. The questionnaire contains questions that represent each variable in this study.

\section{Data Types and Sources}

The type of data in this study is primary data obtained from respondents' responses to the questionnaire sent, while the source of the data comes from individual taxpayer answers that are registered at the KPP Pratama Jakarta Kramatjati.

\section{Analysis Method}

Descriptive statistics

Descriptive statistics in this study are used to provide a description of the character of the research variable using a frequency distribution table that shows the mode number, the range of scores and the standard deviation.

\section{Data Quality Test}

According to Hair et. al (1996, in Sandjojo, 2011), the quality of data generated from the use of research instruments can be evaluated through reliability and validity tests. Each test is to determine the consistency and accuracy of data collected from the use of the instrument.

\section{Classic assumption test}

Testing classic assumptions is done using normality test, multicollinearity test, heterokedasticity test and autocorrelation test. 


\section{Hypothesis testing}

In this study the authors used 4iga independent variables and one dependent variable. The analytical method used to test hypotheses is the multiple regression method, which is regression used to find out how much influence the independent variable has on the dependent variable. The regression equation is as follows: $\mathrm{Y}=\alpha+$ $\beta_{1} X_{1}+\beta_{2} X_{2}+\beta_{3} X_{3}+\beta_{4} X_{4}+\varepsilon$

Information:

$\mathrm{Y}=$ tax payment compliance

$\alpha=$ constant

$\beta \quad=$ regression coefficient

$\mathrm{X}_{1} \quad$ =age, where: $1=40$ years and above; $0=17-39$ years old.

$\mathrm{X}_{2}$ = education, where: $1=$ higher education; $0=$ low education

$\mathrm{X}_{3}=$ Gross Income, where: $1=$ above 5.5 million; $0=$ ranging between Rp. 2.7-5.4 million

$\mathrm{X}_{4}=$ moral

$\varepsilon \quad=$ error

In this study, the significance level $(\alpha)$ of 0.05 or $5 \%$ was used. This multiple regression analysis was carried out with the help of the SPSS (Statistical Package For Social Sciences) Release 22.0 for Windows program so that the coefficient of determination, the statistical value of $\mathrm{F}$ and the statistical value of $\mathrm{t}$ were used in hypothesis testing.

\section{RESEARCH RESULTS AND DISCUSSION}

\section{Research Data Description}

Descriptive analysis is calculated based on the percentage of respondents' answers to research questions using the mean value of each indicator proposed to describe the perceptions of all respondents. Based on the mean (mean), then the respondents' perceptions are interpreted using the three-box method criteria (Ferdinand, 2006), namely: $10.00-40=$ low, $40.01-70=$ moderate, and $70.01-100=$ high .

Table 1.3 Descriptive Statistics Results

\begin{tabular}{|l|c|c|c|c|c|}
\hline \multicolumn{1}{|c|}{ Variable } & $\begin{array}{c}\text { Indeks } \\
\text { Value }\end{array}$ & Minimum & Maksimum & Mean & $\begin{array}{c}\text { Std. } \\
\text { Deviation }\end{array}$ \\
\hline Age & - & 0 & 1 & 0,77 & 0,425 \\
\hline Education & - & 0 & 1 & 0,88 & 0,329 \\
\hline Gross Income & - & 0 & 1 & 0,59 & 0,495 \\
\hline Moral & 77,22 & 7 & 30 & 23,17 & 3,927 \\
\hline Tax payment compliance & 76,77 & 6 & 25 & 19,18 & 3,719 \\
\hline
\end{tabular}

Source: Primary data processed

The following are descriptive statistical results about the research variables as follows: The age variable of taxpayers has a minimum value of 0 and a maximum value of 1 . The average age of taxpayers is 0.77 with a standard deviation of 0.425 . On average of 0.77 or $77 \%$, it can be concluded that the majority of individual taxpayers who are registered at KPP Pratama Jakarta Kramatjati are of productive age.

The variable of the Taxpayer education has a minimum value of 0 and a maximum value of 1 . The average taxpayer education is 0.88 with a standard deviation of 0.329 . On an average of 0.88 or $88 \%$, it can be concluded that the majority of individual taxpayers who are registered at KPP Pratama Jakarta Kramatjati are diploma / bachelor educated.

The variable taxpayer gross income has a minimum value of 0 and a maximum value of 1 . The average taxpayer gross income is 0.59 with a standard deviation of 0.495 . On an average of 0.59 or $59 \%$, it can be concluded that the majority of individual taxpayers who are registered at KPP Pratama Jakarta Kramatjati are earning above 5.4 million.

The moral variable of taxpayers has a minimum value of 7 and a maximum value of 30 . The moral average of taxpayers is 23.17 with a standard deviation of 3,927 . While the frequency index value of 77.22 . With a frequency index value of 77.22, it can be concluded that the perception of respondents 'answers on taxpayers' moral variables is in the high category, because it is in the range of values between $70.01-100$.

The tax compliance variable has a minimum value of 6 and a maximum value of 25 . The average tax payment compliance is 23.17 with a standard deviation of 3,719 . While the frequency index value is 76.77 . With a frequency index value of 76.77, it can be concluded that the perception of respondents' answers to the variable tax compliance in the high category, because it is in the range of values between $70.01-100$. 


\section{Data Quality Test}

Validity test

This test is intended to measure the validity of a questionnaire in measuring a contract. And at the same time reinforce the results of previous calculations that all variables measured using the Likert scale can be used for further data processing. Validation Test Results for each variable can be seen in the following table:

Table 1.4 Validity Test Results

\begin{tabular}{|l|c|c|c|}
\hline \multirow{4}{*}{ Variable } & $\begin{array}{c}\text { No. } \\
\text { Item }\end{array}$ & Correlation Value & Status \\
\hline \multirow{4}{*}{ Moral } & Q1 & 0,637 & Valid \\
\cline { 2 - 4 } & Q2 & 0,775 & Valid \\
\cline { 2 - 4 } & Q3 & 0,832 & Valid \\
\cline { 2 - 4 } & Q4 & 0,825 & Valid \\
\cline { 2 - 4 } & Q5 & 0,674 & Valid \\
\cline { 2 - 4 } & Q6 & 0,570 & Valid \\
\hline \multirow{4}{*}{ Tax payment compliance } & Q7 & 0,790 & Valid \\
\cline { 2 - 4 } & Q8 & 0,708 & Valid \\
\cline { 2 - 4 } & Q9 & 0,851 & Valid \\
\cline { 2 - 4 } & Q10 & 0,879 & Valid \\
\cline { 2 - 4 } & Q11 & 0,860 & Valid \\
\hline
\end{tabular}

\section{Source: Primary data processed}

\section{Reliability Test}

The reliability test is carried out with reference to Cronbach Alpha 0.60. Table 1.5 shows that all instruments of the tested variables have Cronbach alpha above 0.60, so the test results are quite satisfactory because all instruments have a high level of reliability, so they can be used for further data processing. Reliability Test Results for each variable can be seen in the following table:

Table 1.5 Results of Reliability Testing

\begin{tabular}{|c|l|c|c|}
\hline No & \multicolumn{1}{|c|}{ Variable } & Cronbach Alpha coefficient & Number of Instruments \\
\hline 1 & Moral & 0,849 & 6 \\
\hline 2 & Tax payment compliance & 0,750 & 5 \\
\hline
\end{tabular}

\section{Source: Primary data processed}

\section{Classic assumption test \\ Normality test}

Testing for normality using the Lilliefors test. Provisions in the error test are if the statistic $\mathrm{L}$ count $<\mathrm{L}$ table $(\alpha=$ $0.05)$, then the error data is normally distributed. But if $\mathrm{L}$ count $>\mathrm{L}$ table $(\alpha=0.05)$, then the data is not normally distributed. Thus the overall results of the normality test calculation using the Lilliefors test can be seen in the summary in table 1.6.

Table 1.6 Summary of the Normality Test

\begin{tabular}{|c|c|c|c|c|c|c|}
\hline \multirow{2}{*}{ No } & \multirow{2}{*}{ Estimated } & \multirow{2}{*}{$\mathbf{n}$} & \multirow{2}{*}{ L count } & \multicolumn{2}{|c|}{ L Table } & \multirow{2}{*}{ Decision } \\
\cline { 5 - 6 } & & & & $\boldsymbol{\alpha}=\mathbf{0 , 0 5}$ & $\boldsymbol{\alpha}=\mathbf{0 . 0 1}$ & \\
\hline 1 & Y on X1 & 85 & -0.1082 & 0.0961 & 0.1118 & Normal \\
\hline 2 & Y on X2 & 85 & -0.1083 & 0.0961 & 0.1118 & Normal \\
\hline 3 & Y on X3 & 85 & -0.1080 & 0.0961 & 0.1118 & Normal \\
\hline 4 & Y on X4 & 85 & -0.1003 & 0.0961 & 0.1118 & Normal \\
\hline
\end{tabular}

Source: Primary data processed

\section{Multicollinearity Test}

The results of tolerance calculation according to Table 1.7 show that there are no independent variables that have a tolerance value of less than $10 \%$; all tolerance values are more than $10 \%$; which means there is no correlation between variables. The results of the calculation of the value of the variance inflation factor (VIF) also show the same thing, there are no independent variables that have a VIF value of more than 10; the value of the variance inflation factor (VIF) are all less than 10. The conclusion is that there is no multicollinearity between the independent variables in the regression model based on the tolerance value test. 
Table 1.7 Multicollinearity Test Results

\begin{tabular}{|l|c|c|}
\hline \multirow{2}{*}{ Variabel } & \multicolumn{2}{c|}{ Collinearity Statistics } \\
\cline { 2 - 3 } & Tolerance & VIF \\
\hline Age & 0,989 & 1,011 \\
\hline Education & 0,984 & 1,016 \\
\hline Gross Income & 0,982 & 1,018 \\
\hline Moral & 0,991 & 1,010 \\
\hline
\end{tabular}

Source: Primary data processed

\section{Autocorrelation Test}

Autocorrelation test is used to determine whether there is a correlation between the error of the intruder in a certain period and the error of the interfering period before. A good regression model is a regression that is free from autocorrelation. Autocorrelation test can be done by Durbin-Watson (DW) testing. The results of the autocorrelation test can be seen in Table 1.8:

Table 1.8 Autocorrelation test results

\begin{tabular}{|l|c|r|r|r|r|}
\hline Model & R & R Square & Adjusted R Square & Std. Error of the Estimate & Durbin-Watson \\
\hline 1 & $0,759^{\mathrm{a}}$ & 0,576 & 0,556 & 2,480 & 2,189 \\
\hline
\end{tabular}

Source: Primary data processed

Based on SPSS output, the Durbin Watson statistical value is 2.189. While from the Durbin Watson table with $\mathrm{n}=90$ and $\mathrm{k}=4$, we get $\mathrm{d}$ tables, namely $\mathrm{dl}$ (outer boundary) $=1.566$ and du (inner limit) $=1.751$ with a significance level of 5\%,4-du=2,249; and 4-dl =2,434; then from the calculations concluded that the DW-test is located in the test area. This can be seen in Figure 1.2 as follows:

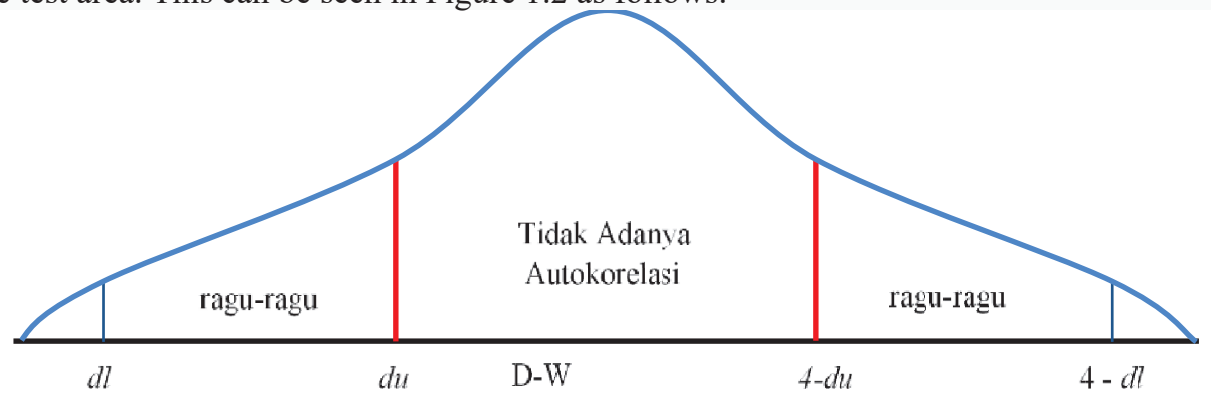

Figure 1.2 Watson Durbin Test

In accordance with Figure 1.2 it shows that Durbin-Watson is in an area of no autocorrelation. Referring to Ghozali (2010), the regression model in this study is free from the autocorrelation problem because the Durbin Watson values are between du and 4 du.

\section{Heteroscedasticity Test}

Detection of heterokedastisitas are: 1) Probability value $>0.05$ means free from heterokedastisitas. 2) Probability value $<0.05$ means that it is exposed to heterokedasticity. The test results using the Spearman rank test can be seen in the following table 1.9:

Table 1.9 Heteroscedasticity Test Results

\begin{tabular}{|l|l|l|r|r|r|r|}
\hline \multicolumn{2}{|c|}{} & $\mathbf{X}_{\mathbf{1}}$ & \multicolumn{1}{c|}{$\mathbf{X}_{\mathbf{2}}$} & \multicolumn{1}{c|}{$\mathbf{X}_{\mathbf{3}}$} & $\mathbf{X}_{\mathbf{4}}$ \\
\hline \multirow{3}{*}{ Spearman's rho } & Absres & Correlation Coefficient & $-0,106$ & $-0,096$ & 0,191 & 0,013 \\
\cline { 3 - 7 } & Sig. (2-tailed) & 0,322 & 0,370 & 0,071 & 0,904 \\
\cline { 3 - 7 } & N & 90 & 90 & 90 & 90 \\
\hline
\end{tabular}

Source: Primary data processed

Spearman rank test results in the table above shows the value of the probability of the significance of each variable of $0.322,0.370,0.071$, and 0.904 . Because the significance value of each variable is greater than 0.05 , it can be concluded that the data are free from heterokedasticity.

\section{Hypothesis testing}

\section{Multiple regression analysis}

Multiple regression analysis is used to get the regression coefficient which will determine whether the hypothesis made will be accepted or rejected. By using the multiple linear regression method the following results are obtained: 
Table 1.10 Results of Regression Analysis

\begin{tabular}{|c|c|c|c|c|c|c|c|}
\hline Information & B & $\mathbf{T}_{\text {count }}$ & Sig & T table & $\operatorname{adj} \mathrm{R}^{2}$ & $F_{\text {count }}$ & Sig \\
\hline (Constant) & 0,357 & & & \multirow{5}{*}{1,663} & \multirow{5}{*}{0,556} & \multirow{5}{*}{28,814} & \multirow{5}{*}{0,000} \\
\hline Age & 1,609 & 2,589 & 0,011 & & & & \\
\hline Education & 1,610 & 2,002 & 0,049 & & & & \\
\hline Gross Income & 0,856 & 1,598 & 0,114 & & & & \\
\hline Moral & 0,676 & $\begin{array}{r}10,05 \\
8\end{array}$ & 0,000 & & & & \\
\hline
\end{tabular}

Source: Primary data processed

Based on the results of the regression tests above, an equation can be formed as follows: $\mathbf{Y}=\mathbf{0 , 3 5 7}+$ $1,609 X_{1}+1,610 X_{2}+0,856 X_{3}+0,676 X_{4}+e$

\section{Determination Coefficient Test $\left(\mathbf{R}^{2}\right)$}

From table 1.10 it is known that the adjusted $\mathrm{R}$ square value is 0.556 . This means that $55.6 \%$ compliance with tax payments can be explained by variations in independent variables, namely age of taxpayers, taxpayer education, gross income of taxpayers, and morale of taxpayers, the remaining $44.4 \%(100 \%-55.6 \%)$ is explained by other causes outside the model.

\section{Simultaneous Significance Test (Statistical Test F)}

From the Anova test or the F test in table 1.10 above, the $\mathrm{F}$ value is 28.814 with a significance probability that indicates 0,000 . Test probability values are much smaller than $\alpha=0.05$. This shows that simultaneously (simultaneously) compliance with tax payments is influenced by the age of taxpayers, taxpayer education, gross income taxpayers, and moral taxpayers.

\section{Significance Test of Individual Parameters (t Test)}

$\mathrm{T}$ test is performed to determine whether the independent variables in the regression model have an individual effect on the dependent variable. To determine whether a hypothesis is accepted or rejected is to compare $t$ arithmetic with ttable and its significance value in this study using a significance level of 0.05 . In this case, the table value is 1.663 .

Partial test results ( $\mathrm{t}$ test) in table 1.10 above show that the taxpayer's age variable has a positive and significant effect on tax payment compliance, which can be seen from the comparison between ttable and tcount, namely ttable <tcount, with ttable 1.663 and tt 2.589 as well as the level of significance is below 0.05 . Thus Ha1 received.

Taxpayer Education has a positive and significant effect on tax payment compliance, which can be seen from the comparison between ttable and tcount, namely ttable <tcount, with a ttable value of 1.663 and tcount 2.002 and a significance level below 0.05 . Thus Ha2 received.

Gross income of taxpayers has an effect on and significant effect on tax payment compliance, which can be seen from the comparison between ttable and tcount, namely ttable <tcount, with a ttable value of 1.663 and tcount 1.598 and a significance level that is above 0.05 . Thus Ha3 was rejected.

Taxpayer Morale has a positive and significant effect on tax payment compliance, which can be seen from the comparison between ttable and tcount, namely ttable $>$ tcount, with a ttable value of 1.663 and 10.058 and a significance level that is far below 0.05 . Thus Ha4 received.

\section{Discussion}

Effect of Age Taxpayers on Tax Payment Compliance

Research results indicate that the age of taxpayers has a positive and significant effect on tax payment compliance.

This finding supports the results of research by Kurniati (2011), and Isthi (2013), which states that the older the taxpayers are, the greater the chance they will be obedient in paying taxes.

\section{Effects of Taxpayer Education on Tax Payment Compliance}

Research results show that Taxpayer Education has a positive and significant effect on tax payment compliance.

These findings support the findings of Isthi (2013) and Dewi, et al (2014), this is likely due to the level of education that will affect the ability of taxpayers in understanding tax sanctions so that it will affect taxpayer compliance.

According to Ikhsan (2007 in Ishti, 2013), the level of education of taxpayers is a factor that influences the awareness and compliance of taxpayers in paying taxes. With the higher level of education of taxpayers, it is also easier for them to understand tax regulations. This is evidenced by the influence and significant level of 
education of taxpayers to taxpayer compliance in paying taxes. According to Fikriningrum (2012), an understanding of taxation is expected to encourage taxpayer awareness to be willing to pay tax payable. The higher the knowledge and understanding of tax regulations, the higher the taxpayer's willingness to pay taxes.

\section{Effect of gross income of taxpayers on tax payment compliance}

The results of the research show that the taxpayer's gross income has no effect and is not significant to the compliance of tax payments.

The results of this study support the results of Feriyani's research (2007 in Ishti, 2013), which states that the higher the income of taxpayers, the greater the chance they will not comply in paying taxes. This is likely due to the threat of financial sanctions that would be considered more burdensome for low-income taxpayers so that they would be more motivated to comply in paying taxes.

\section{Effect of moral of taxpayers on tax payment compliance}

Research results show that taxpayer morale has a positive and significant effect on tax payment compliance.

The results of this study are in line with the findings of Aryati (2012) and Ishti (2013), which states that taxpayers with moral reasons are relatively more compliant than other taxpayers without moral reasons. In addition, the survey results also show that respondents already have a good level of taxation taxation and tax compliance. Moral taxation is why people are honest in the matter of taxation. Whereas tax compliance can be defined as a condition where taxpayers (WP) fulfill all tax obligations and exercise their tax rights. The results of this study indicate that if the taxpayer is morally good, he will automatically comply with tax regulations.

\section{Conclusions}

Based on the results of the analysis and discussion that has been carried out namely regarding, the following conclusions can be given: 1 . Age Taxpayers have a positive effect on compliance with paying taxes; 2 . Taxpayer Education has a positive effect on compliance with paying taxes; 3. Taxpayers' Bruro Income has no effect on compliance with paying taxes; and 4. Moral Taxpayers have a positive effect on compliance paying taxes.

\section{Limitation}

This research is inseparable from the shortcomings and limitations. Limitations in this study are as follows: 1. This study only uses an Individual Taxpayer as a sampel; 2. Respondents' perceptions submitted in writing in the form of questionnaire instruments greatly affect the validity of the results of the questionnaire because they are not accompanied, so the possible answers given do not correspond to the actual size scale or do not correspond to the intent and purpose of the question.

\section{Implication}

The implication of the results of this study is that in the condition of taxpayers who are still low in their awareness and compliance in carrying out their tax obligations, the Directorate General of Taxes can expand the application of final tax rates and expand the object of tax collection and deductions both PPh and PPN and PPnBM. This policy can be implemented to secure state revenue, although it tends to be unfair and unprofitable for taxpayers because of the loss of the right to credit taxes and take into account various business costs in calculating the tax payable. In this connection, it is also necessary to increase the knowledge of community taxation through intensive, consistent and continuous tax education especially starting from the elementary school level to tertiary level and tax education in the family environment at home. In addition, it is also necessary to increase the quantity and quality of tax education counseling so that people are more aware and obedient in carrying out their tax obligations.

\section{Suggestions}

As explained earlier that this study contains limitations. But the results of this study can at least motivate further research. By considering the existing limitations, it is expected that future research will improve the following factors: 1. Future studies need to further examine using other variables to further strengthen the effect of tax revenue performance; 2. The sample used in subsequent studies should be separated between individual taxpayers and corporate taxpayers; 3 . The method used in subsequent studies uses a questionnaire that is added to the open question accompanied by when filling it in, so that the answers given by the respondent can be directed according to the intent and purpose of the question, and use the interview method.

\section{BIBLIOGRAPHY}

Ajzen, Icek, 2002. Constructing a TPB Questionnaire: Conceptual and Methodological Considerations. September (Revised January, 2006).

Aryati, Titik, 2012. Analisis Faktor-faktor Yang mempengaruhi Tingkat Kepatuhan Wajib Pajak Badan. Media 
Ekonomi dan Manajemen, Vol 25. No 1 Januari

Cahyowati, Nur. 2011. Model Moral dan Kepatuhan Perpajakan : Wajib Pajak Orang Pribadi. JAAI, Vol. 15 No. 2 Desember

Dewi Fitriyani, Eko Prasetyo, Reni Yustien, Achmad Hizazi. 2014. Pengaruh Gender, Latar Belakang Pekerjaan, dan Tingkat Pendidikan Terhadap Kepatuhan Wajib Pajak. Jurnal InFestasi. Vol 10, No 2

Elin Dwi Mareti, dan Susi Dwimulyani. 2019. Pengaruh Pemahaman Peraturan Perpajakan, Kualitas Pelayanan Fiskus, Sanksi Pajak dan Tax Amnesty Terhadap Kepatuhan Wajib Pajak dengan Preferensi Resiko sebagai Variabel Moderasi. Prosiding Seminar Nasional Pakar ke 2 Tahun 2019

Ghozali., Imam. 2013. Aplikasi Analisis Multivariate Dengan Program IBM SPSS 21 (ed 7). Semarang: BPUniversitas Diponegoro.

Isthi Wahyuning Tyas. 2013. Pengaruh Umur, Pendidikan, Penghasilan Bruto, dan Moral Terhadap Kepatuhan Pembayaran Pajak (Studi Empiris WPOP Usahawan pada Mall Ciputra). Jurnal TEKUN. Vol. IV, No. 02,

Jogianto. 2015. Teori Portofolio dan Analisis Investasi. Edisi 9. Yogyakarta: PT BPFE.

Kurniati, Amalia. 2011. Analisis Pengaruh Sosialisasi, Sanksi Dan Faktor-Faktor Demografi Terhadap Kepatuhan Wajib Pajak PBB Di Surakarta. Jurnal Bisnis Ekonomi, Volume 15, No.2 September 2011

Mardiasmo. 2016. Perpajakan Edisi Terbaru 2016. Yogyakarta: ANDI.

Peraturan Menteri Keuangan Nomor 235/KMK.03/2003 tentang kriteria wajib pajak patuh dalam pengembalian pendahuluan kelebihan pembayaran pajak.

Simanjuntak, Timbul Hamonangan dan Mukhlis, Iman. 2012. Dimensi Ekonomi Perpajakan dalam Pembangunan Ekonomi. Jakarta: Raih Asa Sukses.

Sri Yuli Ayu Putri. 2018. Pengaruh Work Interfering With Family, Family Interfering With Workdan Orientasi Etika Terhadap Turnover Intentionsdengan Job Satisfaction sebagai Variabel Intervening (Studi Empiris Pada Auditor Kap Jakarta Terdaftar di Ojk). MENARA Ilmu, Vol. XII Jilid III No.79 Januari 2018

Sukandarrumudi. 2012. Metodologi Penelitian. Yogyakarta: Gadjah Mada University Press.

Trisna, Estralita \& Ompusunggu, Parulian, Arles. 2010. Pengaruh umur, pendapatan, moral Terhadap Pembayaran Pajak dan Tax Evasion. Jurnal Ilmiah Akuntansi, Vol.10 No.1, September, hal. 26-44

Undang-undang Nomor 28 Tahun 2007 tentang Ketentuan Umum Perpajakan.

Waluyo, 2011. Perpajakan Indonesia, Edisi 10 buku 1. Jakarta : Salemba Empat

Wening Estiningsih, dan Indra Setiawan Purba. 2014. Faktor-Faktor yang Mempengaruhi Kepatuhan Pajak Usaha Kecil Menengah (UKM). Journal of Applied Business and Economics, Vol. 1 No. 2 